\title{
Rise and reduction of induced earthquakes in the Groningen gas field, 1991-2018: statistical trends, social impacts, and policy change
}

\author{
Charles Vlek ${ }^{1}$ (D)
}

Received: 31 July 2018 / Accepted: 29 December 2018 / Published online: 18 January 2019

(c) The Author(s) 2019

\begin{abstract}
Over 320 induced earthquakes with magnitude $M \geq 1.5$, including 38 with $M \geq 2.5$ in the Groningen gas field, the Netherlands, are statistically analysed, and their societal impacts and recent policy changes reviewed. Increased seismicity indicates that the $900 \mathrm{~km}^{2}$ large, $3 \mathrm{~km}$ deep and $100 \mathrm{~m}$ thick sandstone reservoir has become increasingly vulnerable to further extraction, especially after 2001 and $60 \%$ depletion of the total 2800 billion cubic meters (bcm). Regardless of stepwise reductions in annual extraction: from $54 \mathrm{bcm}$ in 2013 to $20 \mathrm{bcm}$ in 2018, well-fitting trends over 1991-2018 reveal a steady growth of seismic activity per unit of gas extraction. This would imply that, before full resource depletion, some 500 more earthquakes with $M \geq 1.5$ might occur, including 50 with $M \geq 2.5,6$ with $M \geq 3.5$, and 1 with $M \geq 4.5$. Meanwhile, thousands of residents have been suffering from advanced building damage, diminishing property values, disturbing home reinforcement, and various stress-related health complaints. This has spurred a cascade of judgements, decisions and actions by responsible authorities during 2013-2018, topped by the Dutch cabinet's March 2018 decision to reduce Groningen gas extraction to below 12 bcm in 2022 and to end all field operations by 2030 . This would reduce the remaining number of risky earthquakes with $M \geq 2.5$ to some seven or eight, with one expected $M_{\max } \approx 4.0$. Until 2022 , however, seismic hazard and risk would only decrease under 'average' winter conditions. By December 2018, there has been considerable uncertainty about the actual course of decreasing extraction. Meanwhile, a controversial building-reinforcement programme is being greatly reduced.
\end{abstract}

Keywords Induced earthquakes $\cdot$ Gas extraction $\cdot$ Groningen field $\cdot$ Seismic risk

\section{Introduction}

Induced earthquakes up to a Richter magnitude $M$ of 5.0 are a well-known phenomenon around projects of hydrocarbon extraction, wastewater injection, and hydraulic fracturing (Grasso 1992; Nicholson and Wesson 1992; Keranen et al. 2014; Walsh and Zoback 2015; Weingarten et al. 2015; Atkinson et al. 2016; Zhao et al. 2018), whereby the causes of seismic hazard and the limitation of seismic risk are outstanding topics of international research attention. Foulger et al. (2018) document that for hydrocarbon extraction, induced earthquakes generally stay below M 5.0.

A recent, long-emerged but now deeply investigated example is the induced earthquake activity from decades of

Charles Vlek

c.a.j.vlek@rug.nl

1 Department of Behavioural and Social Sciences, University of Groningen, Grote Kruisstraat 2/I, 9712 TS Groningen, The Netherlands substantial gas extraction in the north-eastern Netherlands; see Fig. 1. Here, Europe's largest gas field in the Dutch province of Groningen has been operated since 1963 by the NAM, the Netherlands Petroleum Company, a joint venture of Shell and ExxonMobil established in 1947. Despite major policy changes, the Groningen field-now $80 \%$ depletedhas been and still is highly important for energy security in the Netherlands and various neighbouring countries, and as a major source of Dutch government income.

In the Groningen field, light earthquakes (EQs) of magnitude $M<2.5$ (Richter) started to occur in 1991, with around $45 \%$ of resource depletion. Since then they have increased in number and magnitude, especially after 2001 and so far until 2014; see Fig. 3b below.

Earthquakes with magnitude $1.0 \leq M \leq 3.0$ on the Richter scale are generally considered 'light' and unproblematic. In the province of Groningen (pop. 600,000), however, the limited depth $(3 \mathrm{~km})$ of the EQs, the relatively soft and wet surface soil (clay, peat, sand), and the long repetitiveness of seismic activity all contribute to considerable damage and 


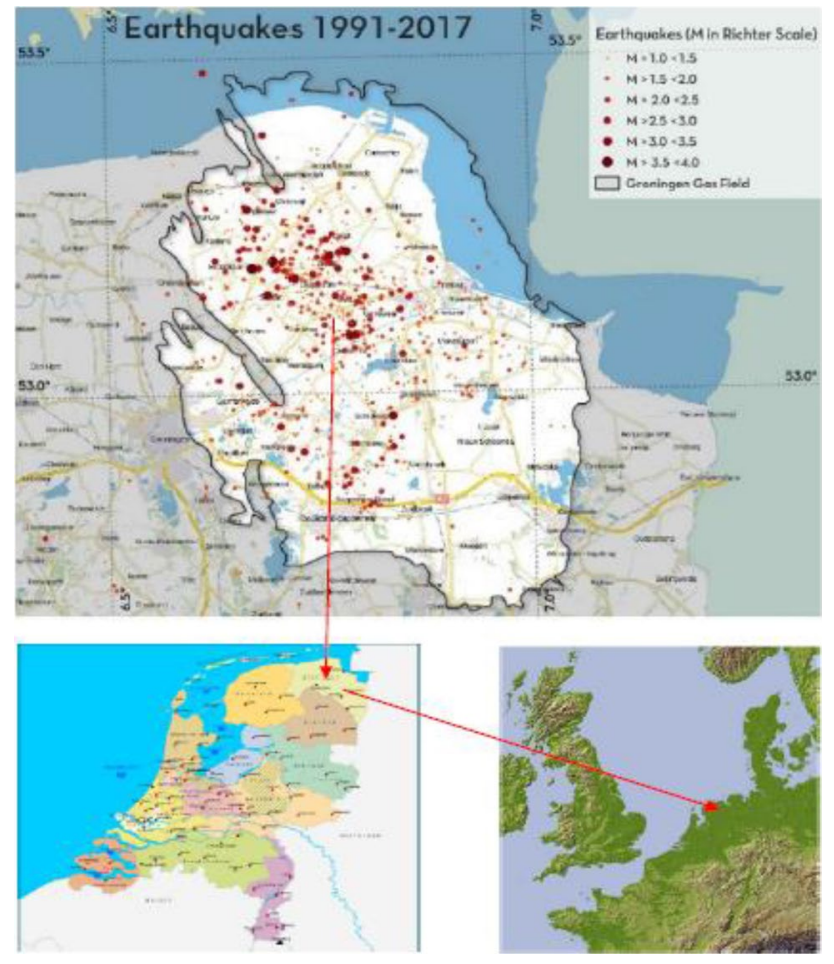

Fig. 1 Top: Dutch province of Groningen with outline of $35 \times 25 \mathrm{~km}$ gas field (black line) and earthquakes 1991-2017 (dotted, with $M \geq 1.0$ ); in collaboration with the University of Groningen Geological Service. Bottom: The Netherlands (left), in north-western Europe

(computed) safety risks over time-in a tectonically inactive region which never needed to be EQ resistant. Illustrative examples of building damage can be seen via (a.o.) https://www.google.nl/search?q=foto's+aardbevingsscha de $\&$ tbm $=i s c h \&$ tbo $=u \&$ source $=$ univ \&sa $=X \& v e d=0 a h U K$ Ewi Y k MW $58 Z$ z WA X LhrQK H YvED $0 \mathrm{~g}$ Q s A QIPw\&biw $=1536 \&$ bih $=768$ (Nov. 2018).

Against the substantial interests of large-scale energy provision as well as significant, albeit recently decreased government revenues, the societal effects of the extractioninduced seismic activity are considerable. Widespread building damage draws numerous victims into a complex circuit of reporting, inspection, planning, restoration and compensation. Private property has decreased in market value (De Kam 2016; Koster and Van Ommeren 2015), and following a recent court order (Gerechtshof Arnhem/Leeuwarden 2018 ) tens of thousands of home owners may be entitled to financial compensation for estimated reductions ('abstract damage') in their property's value.

Experiencing delayed and precarious government action, local residents have become increasingly uncertain, frustrated and angry. Thousands of people, particularly those having experienced a succession of earthquakes, are suffering from anxiety, stress and physical health effects (Postmes et al. 2018). Although no EQ stronger than 3.6 has been recorded thus far, many people fear a 'big bang', while emergency assistance planners reckon with a maximum possible magnitude of 5.0.

This paper is aimed at analysing past developments and future prospects of seismic activity in the Groningen field. This is done against the background of a geophysical hypothesis based on relevant technical documents and further derived from statistical analysis of over 300 well-recorded EQs with magnitude $M \geq 1.5$ (Richter) since 1991. In its purpose and methodical approach, the paper links up with recent work by Bourne et al. (2014, 2018; Bourne and Oates 2015), Dempsey and Suckale (2017), Hagoort (2017), Hettema et al. (2017), Nepveu et al. (2016), and Vlek (2017, 2018).

The following statistical analysis is not a full-fledged probabilistic seismic hazard analysis (PSHA; Cornell 1968; Baker 2008) aimed at estimating peak ground accelerations for various locations. ${ }^{1}$ Instead, the actual 'earthquake catalogue' over 28 years (KNMI 2018) is subjected to statistical analysis in an attempt to reveal a sufficiently valid picture of past developments and future prospects in seismic activity, as related to continuing gas extraction.

The following sections are devoted to, respectively:

1. Trends and trend breaks in gas extraction and seismic activity.

2. Easier earthquake induction as gas extraction accumulates.

3. Estimating higher-magnitude frequencies.

4. Earthquake expectations under further extraction.

5. Reflections on the present analysis.

6. Social impacts and rapid policy change.

7. Concluding remarks.

\section{Trends and trend breaks in gas extraction and seismic activity}

After 55 years of exploitation, the $900 \mathrm{~km}^{2}$ large Groningen field still holds about 600 of the original 2800 billion cubic meters (bcm). In principle, this would allow for a further 30 years of extracting an average annual $20 \mathrm{bcm}$. The induced seismicity is obviously due to increasing reservoir

\footnotetext{
1 A PSHA specifies exceedance probabilities for certain peak ground accelerations (PGAs) at one or more particular sites, due to a plausible set of earthquakes varying in magnitude, location and distance from the relevant site(s). PSHA thus comprises a geophysical source model (the set of EQs), a ground motion prediction equation (GMPE) and a probability-distribution equation allowing to compute integrated exceedance probabilities for (mostly) building-critical PGA values. PSHA is recently being criticized for invalid assumptions, high uncertainties, lack of empirical testing and inability to forecast surprising earthquakes (Stein et al. 2012; Mulargia et al. 2017).
} 


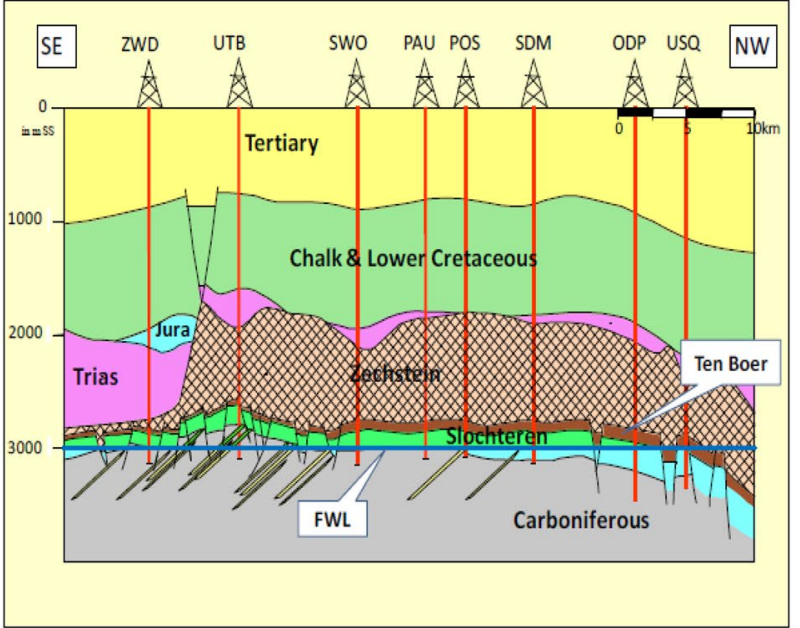

Fig. 2 Left: Geological cross section of the Groningen field ('Slochteren') from south-east (SE) to north-west (NW), in between a carboniferous source layer and a Zechstein rock-salt layer (from NAM

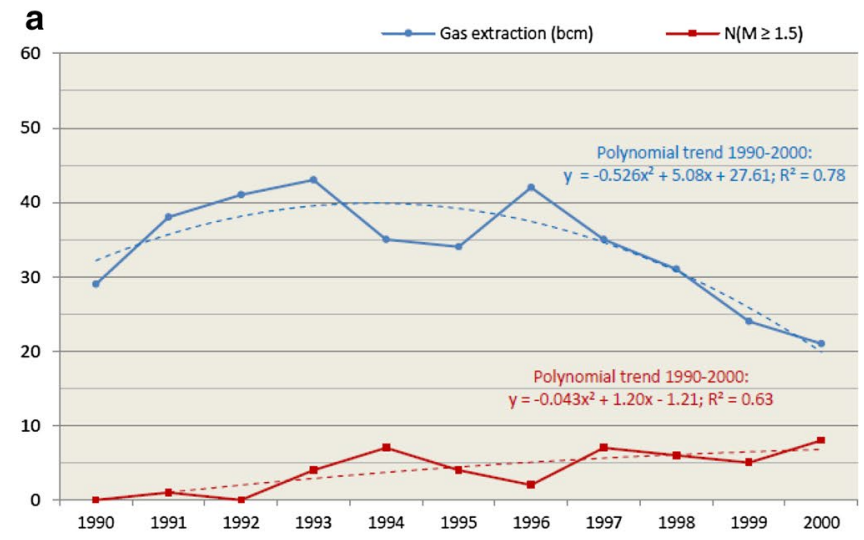

Fig. 3 a, b Annual gas extraction (bcm; upper curve) versus annual number $(N)$ of earthquakes with $M \geq 1.5$ and $\geq 2.5$ (Richter; lower curves). The ordinate $(y)$ fits both annual bcm and earthquake fre-

(porous sandstone) compaction along many faults, which seem to become more critical as gas extraction continues (see Bourne et al. 2014, 2018; Bourne and Oates2015; Van Thienen-Visser and Breunese 2015; Nepveu et al. 2016; Dempsey and Suckale 2017); see Fig. 2 for an impression.

In the present paper, only EQs with $M \geq 1.5$ (abt. 320 in total) are considered because these have been reliably recorded since 1991 (thus, $M \geq 1.5$ may be called the 'magnitude of completeness'), and they are most relevant for the gradual development of building damage. ${ }^{2}$

\footnotetext{
${ }^{2}$ In the present earthquake catalogue, seismic events with $M<1.5$ are deliberately disregarded, except—reservedly — for the set of magnitude-frequency relations in Fig. 6.
}

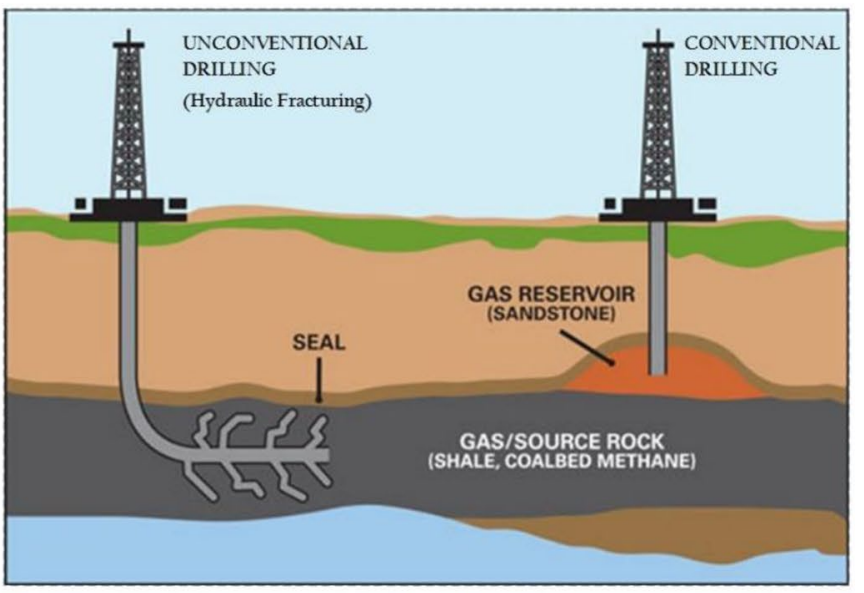

Unconventional/Conventional Natural Gas Extraction

2013, p. 26). At the top, derricks indicate borehole locations. Right: Schematic impression of gas drilling and pressure reduction with possible fault activation

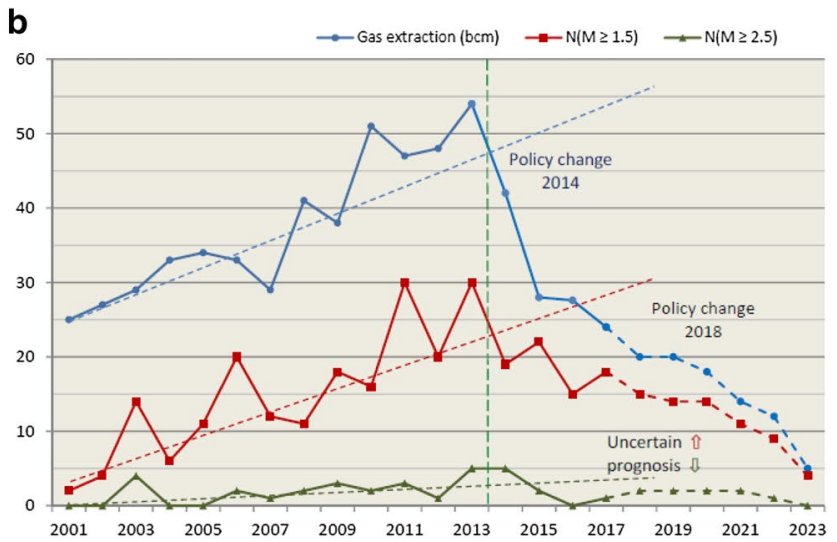

quency. Basic data from NAM (2016a, 2018) and KNMI (2018). Statistical trends (dashed) over time have been separately fitted for periods 1990-2000 (a) and 2001-2013 (b), excluding 2014-2018

Raw EQ data were obtained from the list of all induced EQs in the Netherlands, as provided by KNMI (2018). The spatial distribution of recorded EQs in the Groningen field since 1991 is shown in Fig. 1 (top). For 1986-2018, the 45-page KNMI (2018) national list provides date and time, geographic location, nearest town or village, depth and Richter magnitude of over 1300 extraction-induced EQs in the Netherlands. More than 1000 of these originated in the Groningen field and are easily identified by their geographic coordinates in combination with a provincial map of Groningen. For the reader's convenience, the "Appendix" provides the full table of basic data underlying the following analyses and graphical representations.

Figure 3a, b shows the 1990-2018 course of annual extraction (bcm, upper curve) and the annual number, $N$, of 
EQs with $M \geq 1.5$ and $M \geq 2.5$ (only in $3 \mathrm{~b}$ ), plotted against increasing cumulative extraction since 1963 (abscissa). In Fig. 3a, b, time periods 1990-2000 and 2001-2018 are separately considered because they reveal different trends of, and relationships between, gas extraction and seismic activity.

As Fig. 3a shows, between 1990 and 2000, i.e. between about $45 \%$ and $55 \%$ of total resource depletion, annual $N(M \geq 1.5)$ was rather modest but nevertheless slowly increasing, and it seemed hardly related to variations in gas extraction. Remarkably, during 1996-2000 annual $N(M \geq 1.5)$ kept rising even when annual extraction was steadily reduced from $42 \mathrm{bcm}$ in 1996 down to $20 \mathrm{bcm}$ in 2000. Earthquakes with $M \geq 2.5$ were still rare: they only occurred in 1994 (2), 1998 (1) and 2000 (2), all in the central area of the field. Apparently, reservoir pressure reduction had not yet proceeded far enough for serious seismicity to occur; see also Van Wees et al. (2014). Note that before 1991, light earthquakes or tremors, if occurred, might have gone largely unnoticed due to lack of an adequate network of seismometers.

Around 2001, however, when almost $60 \%$ of the gas reserves had been recovered, EQ activity started to increase more strongly. As Fig. 3b shows, this development went along with significant increases in annual extraction up until 2013 inclusive. Focusing on the period 2003-2016, Nepveu et al. (2016, p. 3358) note: "Production changes are not the sole drivers of the seismicity, production history is expected to play a role as well". The authors (2016) conclude that, after January 2003, seismicity is extraction related, indeed, and that further extraction seems to promote the criticality of the many faults in the reservoir.

From late 2012 onwards, growing social and political concern about the occurrence of stronger, more harmful EQs (notably a 3.6 event in August 2012) led to a range of in-depth studies eventually advancing a policy of stepwise reduction in annual gas extraction, from a new record $54 \mathrm{bcm}$ in 2013 (the old, absolute record being $88 \mathrm{bcm}$ in 1976), down to $42 \mathrm{bcm}$ in 2014, about $28 \mathrm{bcm}$ in 2015/2016 and $24 \mathrm{bcm}$ in 2017.

For the period 2017-2021, an annual volume of $24 \mathrm{bcm}$ was established in September 2016, but already in May 2017 the Dutch government decided that this would be further lowered to 21.6 bcm by October 2017 (EZ 2016, 2017). However, in the wake of a widely disturbing 3.4 quake in January 2018, the government principally decided to lower annual extraction within 5 years to at most $12 \mathrm{bcm}$ and to end the operation of the Groningen field altogether by 2030 (EZ 2018a, b).

In Fig. 3b, the three sets of data points for 2001-2013 (excl. 2014-2018) have been fitted by linear trend lines. Parsimoniously, a linear extrapolation of annual $N(M \geq 1.5)$ seems best, also for $N(M \geq 2.5)$ with $R^{2}=0.32$ only, indicating a much weaker relationship_not surprising because of much fewer events.

The almost conjointly rising 2001-2013 trend lines in Fig. $3 b$ may be, and were, reasonably interpreted to reflect a causal association (Muntendam-Bos and De Waal 2013; Van Thienen-Visser and Breunese 2015). This interpretation is strengthened by what Fig. $3 \mathrm{~b}$ shows to have happened after 2013, when annual gas extraction was significantly diminished. Earthquake frequency also went down, from $N$ $(M \geq 1.5)=30$ in 2013 to $N(M \geq 1.5)=14$ in 2016, while at the same time annual $N(M \geq 2.5)$ decreased from five to zero.

However, during $2017 N(M \geq 1.5)$ turned out to be 18 , including one EQ with $M \geq 2.5$. Over entire 2018, 15 EQs with $M \geq 1.5$ have occurred, including a 3.4 quake on January 8 and a 2.8 event on April 13 .

Note that in Fig. 3b, the covariation of annual gas extraction and earthquakes is far from smooth; there is considerable natural variability in seismic activity, apparently due to variations in the location and nature of faults, stresses and (delayed) reservoir compaction in response to continuing pressure reduction (see also Bourne et al. 2014, 2018; Bourne and Oates 2015; Dempsey and Suckale 2017).

For a somewhat smoother representation and more comprehensive analysis, let us consider both gas extraction and seismic activity per 2 years across 1991-2018 (14 episodes). Table 1 presents the 2 -year course of both $N(M \geq 1.5)$ and $N$ $(M \geq 2.5)$ in relation to cumulative extraction $\left(\mathrm{bcm}_{\text {cum }}\right)$ since the beginning of the Groningen field operations in 1963. For easy reference, the 2-year extraction volume is separately indicated.

The last row of Table 1 shows that, overall, $N(M \geq 1.5)$ is roughly nine (precisely: 8.53$)$ times larger than $N(M \geq 2.5)$. The logarithm of the ratio $N(M \geq 1.5) / N(M \geq 2.5)$ provides an estimate of the Gutenberg-Richter $b$ value characterizing the frequency distribution of just these two earthquake magnitudes, as explained in Box 1 (see Gutenberg and Richter 1941; Utsu 1999); their overall $b$ value turns out to be 0.932 . $^{3}$ More comprehensive and reliable estimates of $b$ will be presented in connection with Fig. 6, "Estimating highermagnitude frequencies".

Figure $3 \mathrm{a}, \mathrm{b}$ and Table 1 reveal that for comparable 1- or 2-year extraction rates more EQs tend to occur as bcm cum $_{\text {. }}$ increases. This suggests that continuing reservoir compaction, due to continuous pressure reduction, makes the porous sandstone layer holding the (remaining) gas more and more earthquake-prone-particularly after 2001—in relation to further extraction.

\footnotetext{
${ }^{3}$ In contrast to 'total' $b=0.93$, for 'subtotal' 1991-2004 $b=0.88$, reflecting relatively more events (abt. $2 / 15$ rather than 2/17) with $M \geq 2.5$.
} 
Table 1 Cumulative and 2-year volume of gas extraction (bcm), 2-year $N(M \geq 1.5), 2$-year $N$ $(M \geq 1.5)$ per $30 \mathrm{bcm}$ (see also Fig. 5) and $N(M \geq 2.5)$, per the end of every 2 nd year over 1991-2018

\begin{tabular}{llllll}
\hline 2nd of 2-year period & Bcm $_{\text {cum }}(1963-)$ & Two-year bcm & $\begin{array}{l}\text { Two-year } N \\
(M \geq 1.5)\end{array}$ & $\begin{array}{l}N(M \geq 1.5) \text { per } \\
30 \text { bcm extracted }\end{array}$ & $\begin{array}{l}\text { Two-year } N \\
(M \geq 2.5)\end{array}$ \\
\hline 1992 & 1320 & 79 & 1 & 0.38 & 0 \\
1994 & 1398 & 78 & 11 & 4.23 & 2 \\
1996 & 1474 & 76 & 6 & 2.37 & 0 \\
1998 & 1540 & 66 & 13 & 5.91 & 1 \\
2000 & 1585 & 45 & 11 & 7.32 & 2 \\
2002 & 1636 & 51 & 6 & 3.53 & 0 \\
2004 & 1698 & 62 & 20 & 9.69 & 4 \\
Subtotal & - & - & 68 & - & 2 \\
2006 & 1765 & 67 & 31 & 13.88 & 3 \\
2008 & 1835 & 70 & 23 & 9.85 & 5 \\
2010 & 1924 & 89 & 34 & 11.46 & 4 \\
2012 & 2019 & 95 & 50 & 15.8 & 10 \\
2014 & 2115 & 96 & 49 & 15.3 & 2 \\
2016 & 2170 & 55 & 36 & 19.6 & 38 \\
2018 & 2213 & 43 & 33 & 23.0 & - \\
Total & - & - & 324 & - & 38 \\
\hline
\end{tabular}

Data for 14 successive 2-year periods starting at 1991, i.e. 1991-1992, 1993-1994 and so on, up to 20172018. Basic data from NAM (2016b, updated 2018) and KNMI (2018)

\section{Box 1. Gutenberg-Richter equation for earthquake magnitude-frequency distribution}

Gutenberg-Richter equation: For a given seismic region, $N(M)=10^{\mathrm{a}-\mathrm{bM}}$, whereby $N(M)$ is the number of earthquakes with at least magnitude $M$, and $a$ and $b$ are constants. From this equation one can infer that $b=\log _{10}$ $N(M \geq x)-\log _{10} N(M \geq x+1)=\log _{10}[N(M \geq x) / N$ $(M \geq x+1)]$. When $N(M \geq x)$ and $N(M \geq x+1)$ are known from earthquake statistics, the value of $\mathrm{b}$ can be estimated. This can be done for various magnitude pairs (e.g., $M \geq 1.5$ versus $M \geq 2.5$ ) and for different time periods (e.g., 1991-2003 and 2004-2018). When the $M$-difference amounts to only 0.5 , an estimate of $1 / 2 b$ is obtained. More generally and more validly, $b$ can be estimated as the negative slope coefficient in one or more $\log -\log$ magnitude-frequency distributions, as presented in Fig. 6 below.

\section{Easier earthquake induction as gas extraction accumulates}

This basic hypothesis may be statistically clarified by considering the ratio of $N(M \geq 1.5)$ over the number of bcm of gas extraction in a particular period of time, here 1 and 2 years, and plotting $N(M \geq 1.5) / 10 \mathrm{bcm}$ (per year) and $N$ $(M \geq 1.5) / 30 \mathrm{bcm}$ (per 2 years) against $\mathrm{bcm}_{\text {cum }}$ since 1963 .
Figure 4 shows the number of EQs with $M \geq 1.5$ per $10 \mathrm{bcm}$ in the same year for each of the 28 years between 1991 and 2018. Figure 5 provides a somewhat smoother picture, based on a 2-year count of $N(M \geq 1.5)$ per $30 \mathrm{bcm}$ as a function of $\mathrm{bcm}_{\text {cum }}$ for 14 successive 2-year periods across 1991-2018; see also the 5th column of Table 1.

The best-fitting trend line in Fig. 4 approximates 'noisy' $N(M \geq 1.5) / 10 \mathrm{bcm}$ as a linear function of $\mathrm{bcm}_{\text {cum }}$, with $R^{2}=0.74$ implying that $26 \%$ of the data variance remains unexplained.

Taking statistical uncertainties into account, we may project for a near-future (2019-2022) extraction rate of $20 \mathrm{bcm} /$ year that annual $N(M \geq 1.5)$ would likely fall between $2 \times 6.7 \approx 13 \pm 26 \%$ in 2019 (at $2233 \mathrm{bcm}_{\text {cum }}$ ) and $2 \times 7.3 \approx 15 \pm 26 \%$ in 2022 (at $2300 \mathrm{bcm}_{\text {cum }}$ ), including one or two EQs with $M \geq 2.5$ per year.

More smoothly and steadily than in Figs. 4 and 5 shows the 2-year $N(M \geq 1.5)$ per $30 \mathrm{bcm}$ of extraction in the same period across 1991-2018; numerical values of this ratio are given in the fifth column of Table 1 . The 14 data points in this obviously less noisy representation are equally and rather well fitted by a linear, a quadratic and a logarithmic function of cumulative bcm, with an $R^{2}$ of $0.90,0.90$ and 0.88 , respectively, leaving about $10 \%$ unexplained variance. This appropriately reflects the uncertainty already apparent in Fig. 4. Here again, it is clearly revealed that, as $\mathrm{bcm}_{\text {cum }}$ increased, more EQs occurred per $30 \mathrm{bcm}$ of extraction.

In the short term of 2019-2022 and for the present biennial $2 \times 20=40$ (instead of $2 \times 30$ ) bcm of extraction, we could project some $25-29( \pm 10 \%)$ EQs with $M \geq 1.5$ per 
Fig. 4 Annual $N(M \geq 1.5)$ per $10 \mathrm{bcm}$ of extraction in the same year, as a function of $\mathrm{bcm}_{\text {cum }}$ since 1963. Linear trend function fitted across 19912018 (28 data points), with fit measure $R^{2}=0.74$, extended towards (eventual) full resource depletion at $2800 \mathrm{bcm}_{\text {cum }}$

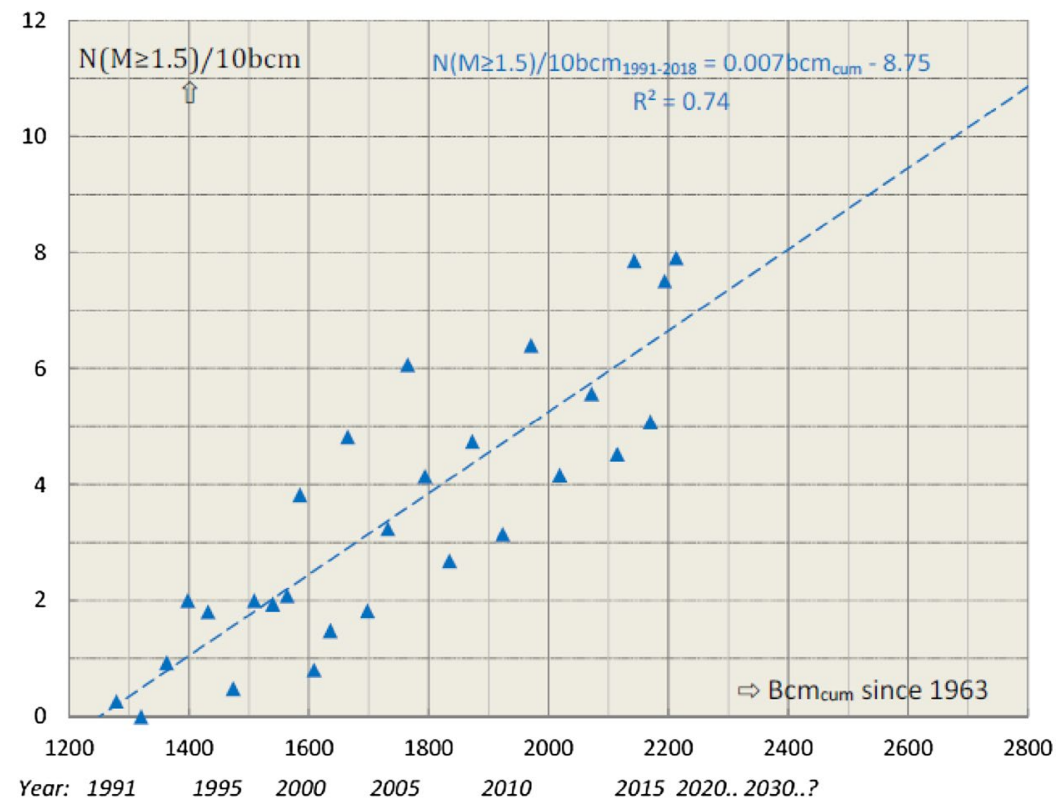

Fig. 5 Two-year $N(M \geq 1.5)$ per $30 \mathrm{bcm}$ of gas extraction in the same period versus cumulative total extraction since $1963(x)$, for 14 periods across 1991-2018. Fitted trend lines describe $N(M \geq 1.5) / 30 \mathrm{bcm}$ as a linear (see figure), a quadratic and a logarithmic function of $\mathrm{bcm}_{\text {cum }}$, respectively. The latter two are: $N(M \geq 1.5) / 30 \mathrm{bcm}$ quadr $=7 \mathrm{E}-06 \mathrm{bcm}_{\text {cum }} 2$ $-0.003 \mathrm{bcm}_{\text {cum }}-6.95$, with $R^{2}=0.90$, and $N$ $(M \geq 1.5) / 30 \mathrm{bcm}_{\log }=38.0 \mathrm{ln}$ $\left(\mathrm{bcm}_{\text {cum }}\right)-273.6$, with $R^{2}=0.88$

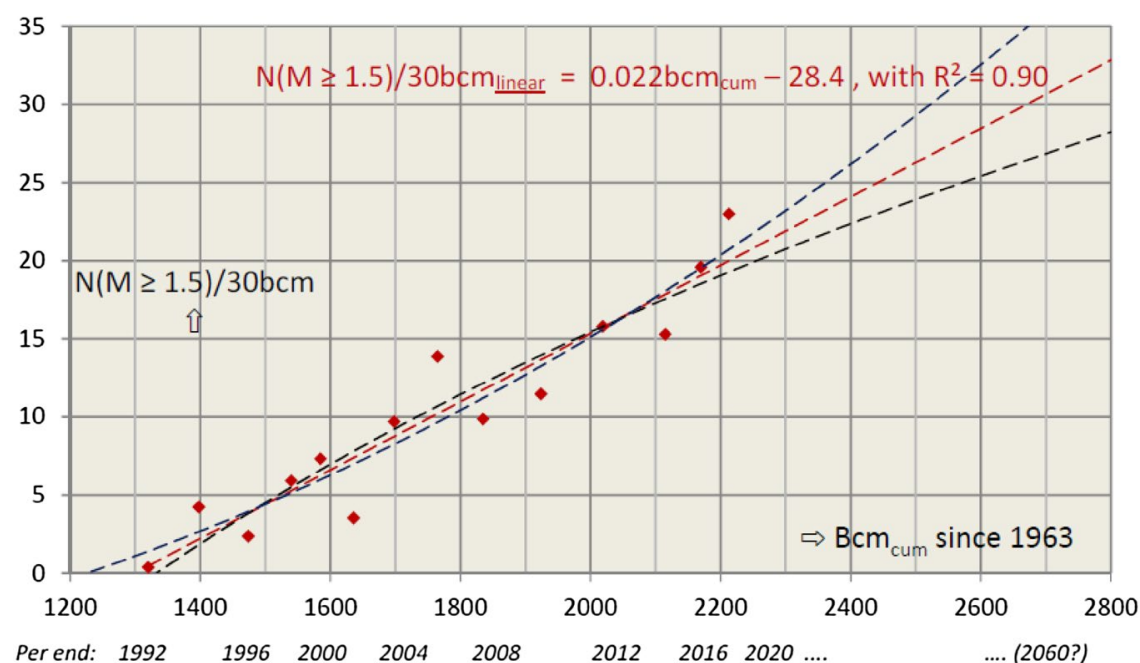

2 years, including three with $M \geq 2.5$. This compares well to the somewhat noisier extrapolation of annual $N(M \geq 1.5)$ falling between 13 and 15, as based on Fig. 4.

As Figs. 4 and 5 clearly show, when gas extraction would be steadily continued, at a rate of 10,20 or $30 \mathrm{bcm} /$ year, the number of EQs, and thus the probability of stronger EQs, is likely to increase again, after its temporary decrease in relation to diminishing annual extraction since 2014; see Fig. 3b.

The remaining $N(M \geq 1.5)$ until total resource depletion, or any lower amount of ultimate $\mathrm{bcm}_{\text {cum }}$, may well be projected-approximately - from the linear trends in Figs. 4 and 5. After 2018, with about $2800-2200=600 \mathrm{bcm}$ to go until full resource depletion, the prognosis based on the linear course of $N(M \geq 1.5) / 10 \mathrm{bcm}$ in Fig. 4 would involve $600 / 10 \times 1 / 2(6.7+10.9)=528$ more EQs with $M \geq 1.5$, whereby 6.7 and 10.9 are the computed 'per $10 \mathrm{bcm}$ ' trend values at 2200 and $2800 \mathrm{bcm}_{\text {cum }}$, respectively.

On the basis of 'smoother' $N(M \geq 1.5) / 30 \mathrm{bcm}$ in Fig. 5, the expected total $N(M \geq 1.5)$ would be $600 / 30 \times 1 / 2$ $(20+33)=530$, with 20 and 33 being the computed linear trend values at 2200 and $2800 \mathrm{bcm}_{\text {cum }}$, respectively. We may thus conclude that after 2018, approximately 500 more EQs with $M \geq 1.5$ could be expected until (eventual) full resource depletion.

In contrast, following the Dutch government's recent policy scenario of reduce-and-finish Groningen gas extraction within the next 12 years (see Fig. 8 below, dashed lines), extracted $\mathrm{bcm}_{\text {cum }}$ would stop at 2300 by 2030 . Then from 2018 on, with $2300-2200=100 \mathrm{bcm}$ of extraction to go, the expected $N(M \geq 1.5)$ until 2030 would be, following Fig. 4: $100 / 10 \times 1 / 2(6.7+7.3) \approx 70$ EQs, and following Fig. 5 (linear 


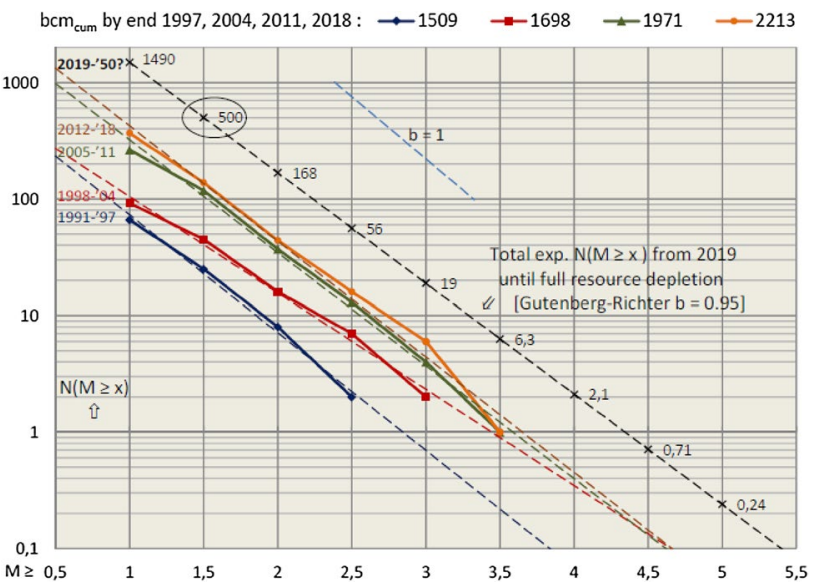

Fig. 6 Magnitude-frequency distributions for four periods of 7 years each, across 1991-2018 (colored lines). Along these lines, from top (most recent) to bottom, linear trend functions are ${ }^{10} \log \mathrm{N}(M \geq x)=$ $y_{2012-2018}=-0.991 x+3.62 ; y_{2005-2011}=-0.969 x+3.48 ; y_{1998-2004}=$ $-0.826 x+2.85 ;$ and $y_{1991-1997}=-1.010 x+2.87$; all with an explained proportion of variance $R^{2} \approx 0.99$. The upper dashed line represents total further-expected $N(M \geq x)$ until (eventual) full resource depletion $\left(2800 \mathrm{bcm}_{\text {cum }}\right)$, starting from $N(M \geq 1.5)=500$ and unfolded with Gutenberg-Richter $b=0.95$ (see below); this line has an off-chart value of 0.08 at $M=5.5$. Non-occurring magnitudes (with zero frequencies) are excluded from the analysis. Note that along the two axes and the '2019-2050?' total-expectation line, (preprogrammed) commas should be dots

trend): $100 / 30 \times 1 \frac{1}{2}(19+23) \approx 70$ as well, whereby the numbers in brackets are the computed trend values at 2200 and 2300 bcm $_{\text {cum }}$ in Figs. 4 and 5, respectively.

\section{Estimating higher-magnitude frequencies}

The widely applied Gutenberg-Richter $b$ value (Box 1) is useful for understanding a more comprehensive EQ magnitude distribution including the likelihood of highermagnitude events that did not yet occur. Given that seismic activity in Groningen has grown with increasing cumulative extraction, here EQ magnitude frequencies are considered separately for the four successive 7-year periods of 1991-1997, 1998-2004, 2005-2011, and 2012-2018, respectively, altogether 28 years with substantially increasing levels of $\mathrm{bcm}_{\text {cum }}$ at the end of each 7-year period. These empirical magnitude-frequency distributions are graphically represented in the lower four, coloured lines of Fig. $6 .{ }^{4}$

\footnotetext{
${ }^{4}$ Note that the $N(M \geq 1.0)$ represented here may be somewhat less reliable because EQs with $M<1.5$ have not been equally well recorded over the entire period 1991-2018.
}

Figure 6 clearly shows that the total number of EQs per 7-year period increases as a function of $\mathrm{bcm}_{\text {cum }}$. Their relative frequency distribution, however, remains rather constant.

The reasonably parallel set of straight lines in Fig. 6 indicates that the Gutenberg-Richter $b$ value varies little over time (or rather: $\mathrm{bcm}_{\text {cum }}$ ) or with increasing EQ magnitude. Based on the fitted straight trend lines for the four 7 -year periods in Fig. 6, the $b$ value can-from most to least recent — be empirically estimated at $0.99,0.97,0.83$ and 1.0, respectively.

About Fig. 6, however, we should carefully note that earthquake frequency in the higher-magnitude range tends to diminish non-linearly (as the solid colored lines clearly suggest). Empirically, in all 28 years after 1990 only three events with $M \approx 3.5$ occurred, and none stronger. Thus the probability of $M \geq 3.5$ may well be lower than could be inferred from the log-linear $b$ values in Fig. 6.

\section{Earthquake expectations under further extraction}

The preceding analyses allow us to forecast further EQ activity depending on whether the full $2800 \mathrm{bcm}$ of Groningen gas would be extracted, or whether extraction would be ended, as now planned, at an expected $2300 \mathrm{bcm}_{\text {cum }}$ in 2030.

\section{Expected seismicity up to full resource depletion}

For estimating an expected magnitude-frequency distribution from 2019 until eventual full resource depletion, let us adopt a general $b$ value of 0.95 ; Zöller and Holschneider (2016), as well as Bourne and Oates (2015, Part 2, p. 33; 2017) give similar values.

Then, starting from total expected $N(M \geq 1.5) \approx 500$ as estimated in "Easier earthquake induction as gas extraction accumulates", we may unfold the (uppermost) expected '2019-2050?'-line in Fig. 6 right-down to $M=5.5$. This would imply that about 56 (=1/9 of 500) EQs with $M \geq 2.5$ might still occur, including six (1/81) with $M \geq 3.5$, and at most one (1/729) with $M \geq 4.5$, until $2800 \mathrm{bcm}_{\text {cum }}$.

Moreover, an estimated 0.24 events with $M \geq 5.0$ might be expected in the next 30-odd years, which roughly translates into an annual probability of 0.008 , or, frequentistically, 1 in 125 years, highly unlikely indeed. To the extent that the

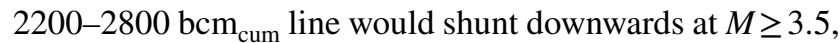
higher-magnitude events would appear to be even less likely.

In March 2016 an international expert panel (NAM 2016c) considered continuing annual gas extraction at 33,27 and $21 \mathrm{bcm}$ and judged these differences not to matter much for $M_{\max }$. The panel concluded that $4.0<M_{\max }<7.0$, with a weighted average of 5.0-assuming that major ruptures 


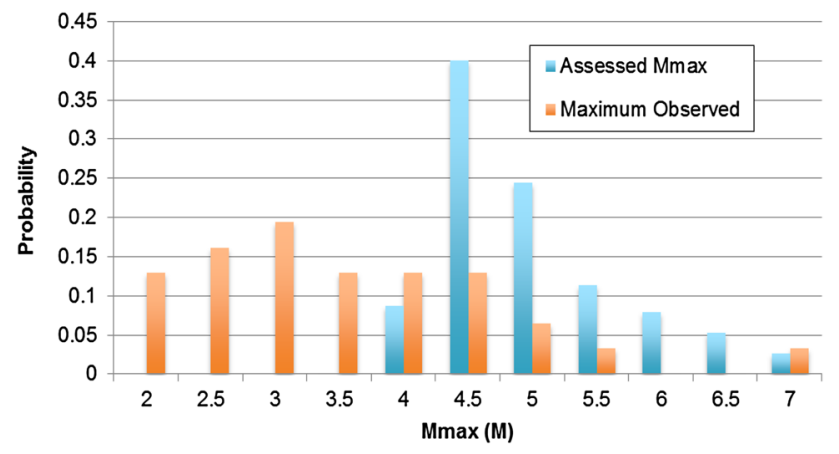

Fig. 7 Probability mass function for possible $M_{\max }$ in the Groningen field, provided that gas extraction would long continue for 33, 27 or $21 \mathrm{bcm}$ per year; from NAM (2016c, p. 8)

might extend outside the reservoir (as had happened in 1976 and 1984 in the Gazli field, Uzbekistan; see Simpson and Leith 1985). The probability mass function for discretized possible values of $M_{\max }$ is given in Fig. 7 (NAM 2016c); the 'observed' $M_{\max }=7$ actually occurred in Uzbekistan.

Spetzler et al. (2018) largely copied this wide-margin assessment, which had meanwhile been significantly moderated by Zöller and Holschneider (2016) who estimated $M_{\max } \approx 4.0$ until 2024 and 'ever possible' $M_{\max } \approx 4.4$. Shapiro et al. (2017) argue that, due to the finiteness of rupture surfaces, the frequency of induced larger- $M$ earthquakes deviates from the Gutenberg-Richter regularity (Box 1 above), and they estimate $M_{\max } \approx 4.2$, under continuing Groningen gas extraction.

In their advanced geophysical-modelling exercise, Dempsey and Suckale (2017) find the expected $M_{\max }$ for 2017-2024 to be rather independent of the annual extraction volume $(21,27$ or $33 \mathrm{bcm}$, as then considered) and that $M_{\max }$ has a probability of about $20 \%$ to exceed $M=3.5$ (i.e. on average, once in 5 years) and a likelihood of 5\% to exceed $M=4.0$ (once in 20 years). Thus, under long-continuing operation of the Groningen field, an $M_{\max } \geq 4.5$ seems extremely unlikely.

\section{Forecast seismicity under 'reduce and finish' extraction}

In contrast to full resource depletion, however, the radical new policy of ending Groningen field operation by 2030 (cf. Fig. 8) raises four critical questions. These are particularly important in view of the regional building-reinforcement operation started in 2015 and slowly developed over 2016-2017 (NCG 2016).

1. When gas extraction goes back from the current $20 \mathrm{bcm}$ to less than $12 \mathrm{bcm}$ in 2022, would the reservoir's seismic activity (soon) decrease accordingly?

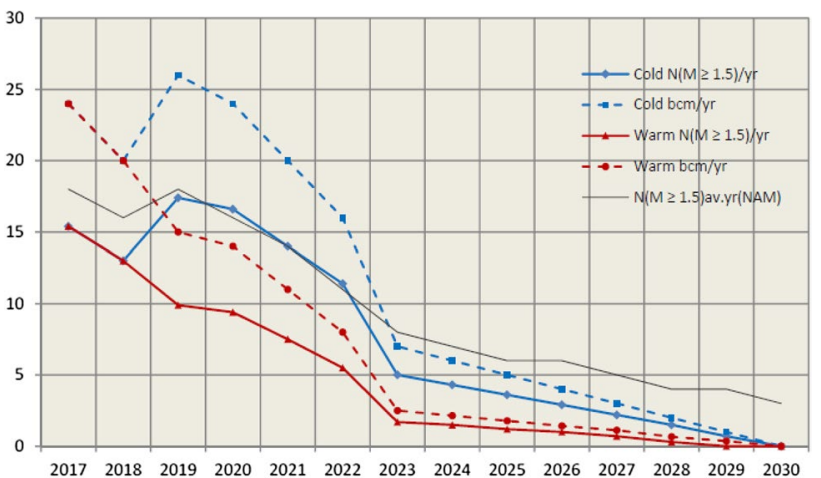

Fig. 8 Annual bcm of extraction and expected annual $N(M \geq 1.5)$ following reduce-and-finish scenarios for generally 'cold', freezing winters-upper two, blue lines-versus 'warm', largely frost-free winters (lower two, red lines) across 2019-2030, with actual extraction data for 2017-2018. The ordinate fits both annual bcm and $N(M \geq 1.5) . N$ $(M \geq 1.5)$ expectations are based on $N(M \geq 1.5) / 10 \mathrm{bcm}$ trend function in Fig. 4, and are roughly $\pm 25 \%$. Actual $N(M \geq 1.5)$ for 2017 is 18; the complete 2018 figure for $N(M \geq 1.5)$ is 15 . The thin grey line represents the 'average temperature' expectation of $N(M \geq 1.5)$ by NAM (2018b, p. 43)

2. When after 2022 at most $10 \mathrm{bcm} /$ year would be extracted until 2030, which further earthquake activity could then be expected?

3. What would be the maximum earthquake magnitude before 2030 ?

4. When extraction would fully stop in 2030, how long would significant EQs still be occurring?

Following the March 2018 'reduce-and-finish' scenario of the Dutch government (EZ 2018b), only 70 EQs with $M \geq 1.5$ would occur before $2300 \mathrm{bcm}_{\text {cum }}$ in 2030 (see "Easier earthquake induction as gas extraction accumulates"). Then, again applying a Gutenberg-Richter $b$ value of 0.95 , we could expect seven to eight EQs to have an $M \geq 2.5$, while at most one would have $M \geq 3.5$. Between $2200 \mathrm{bcm}_{\text {cum }}$ (end 2018) and $2300 \mathrm{bcm}_{\text {cum }}$ (2030, planned), an EQ with $M \geq 4.5$ would be highly unlikely.

More specifically, how many EQs with $M \geq 1.5$ would occur annually over 2018-2030, given the recent 'reduceand-finish' scenario of the Dutch government? This appears to depend on whether there would be generally cold (freezing), average, or 'warm' winters. The dashed lines in Fig. 8 indicate the intended annual extraction volumes for generally cold (upper, blue) versus 'warm' (lower, red) winters (EZ 2018b). ${ }^{5}$ Correspondingly, the solid upper (blue) versus

\footnotetext{
5 The steep dip in annual bcm between 2022 and 2023 has to do with the start of a substantial nitrogen factory aimed at making high-calorific gas from elsewhere equivalent to the low-calorific Groningen gas to which most customers' gas burners are tuned.
} 
lower (red) lines indicate the expected annual $N(M \geq 1.5)$ for the cold versus warm winter scenarios, as computed from the linear $N(M \geq 1.5) / 10 \mathrm{bcm}$ trend function in Fig. 4 . Clearly, expected seismicity goes down as annual bcm is reduced, while annual extraction itself depends on 'cold' versus 'warm' winter conditions. Thus, the short-term environmental safety of risk-exposed residents seems to depend much on predominant winter temperatures.

The thin grey line in Fig. 8 represents expected $N$ $(M \geq 1.5)$ for an 'average winters' scenario, as computersimulated by NAM (2018b) itself. Remarkably, the 'average' NAM expectations for 2019-2022 are (conservatively?) close to the corresponding 'cold' expectations based on Fig. 4 above, while after 2023 they tend to be even higher. We should note, however, that all expectations are surrounded by considerable uncertainties and that precautionary interpretations would yield higher $N(M \geq 1.5)$ expectations.

Given these estimated future EQ frequencies, the critical question 4 may be answered by implication: after Groningen gas extraction has been fully ended around 2030, significant seismic activity will very likely stop within 1 or 2 years; see also NAM (2018b).

\section{Reflections on the present analysis}

The seismic-activity analysis reported above is relatively simple and rests on EQ frequency counts, seismicity/extraction ratios, straightforward trend fitting and extrapolation supported by graphical visualization. Thus the present conclusions and prognoses do not rely on 'cutting edge' geomechanical modelling and/or sophisticated Monte Carlo simulations of faulted-reservoir behaviour (cf. Bourne and Oates et al. 2017; 2018; Dempsey and Suckale 2017).

The principal caveat here is that statistical extrapolation is based on historical observations and their apparent regularity over time; see also Van der Elst et al. (2016). Extrapolation rests on the basic assumption that 'the system' generating these observations keeps behaving as it hasapparently_-done thus far, i.e. in Groningen at least for the past 28 years.

Limiting the analysis to well-recorded events with $M \geq 1.5$, rather than $M \geq 1.0$, obviously reduces the available database and precludes more detailed analysis on the subregional level. An additional problem for statistical analysis of actually recorded events is the 'noisy' natural variability in annual seismic activity. Thus statistical projections about future EQ activity can never be hard predictions, particularly when it gets to the higher magnitudes. To quote Zöller and Holschneider (2016, p. 5): “.. large earthquakes are rare events. Any statements on large earthquakes will therefore be afflicted with high uncertainties". And following Foulger et al. (2018, p. 509): “There is presently no reliable method to predict earthquakes."

Given these reservations, for the Groningen field it has become clear that seismic activity has steadily increased since 1991, slowly at first and more rapidly after 2001. This seems to indicate that the soft reservoir rock started to crack (observably) around 1990, at $45 \%$ of resource depletion, and has become increasingly vulnerable for further gas extraction, especially after 2001 when a cumulative total of $1600 \mathrm{bcm}$ had already been extracted. Continuing extraction at any stable, non-decreasing annual rate (say 10 or $20 \mathrm{bcm} /$ year) would not diminish seismic activity overall, but stable low-rate extraction might reduce the frequency of damaging EQs with $M \geq 2$, due to 'aseismic creep' in the reduction of increasing stress on near-critical faults.

\section{Social impacts and rapid policy change}

Since the 3.6 earthquake near the central village of Huizinge in August 2012, it has become rapidly clear that 50 years of underground Groningen gas extraction was causing increasing surface problems of soil subsidence, building damage and safety risks for numerous provincial inhabitants. Within 5 years this has led to great changes in both gas extraction and EQ protection policies. "Societal problems in 'gas colony' Groningen" offers a sketch of the social and personal impacts of the Groningen EQs. "NAM actions, SodM advice and Minister's decisions" gives an overview of judgements and actions by the main players during the turbulent years 2013-2018.

\section{Societal problems in 'gas colony' Groningen ${ }^{6}$}

During 2014-2018 the social, personal and local-economic impacts of seismic activity in the Groningen field have been variously documented (Van der Voort and Vanclay 2015; Koster and Van Ommeren 2015; De Kam 2016; Perlaviciute et al. 2017; Vrieling et al. 2018; Postmes et al. 2018).

In an early field study conducted in 2013-2014-when annual extraction still exceeded $40 \mathrm{bcm}$, see Fig. 3b-Perlaviciute et al. (2017) interviewed over 1200 residents living at various distances from the central earthquake area. During three successive episodes, interviewers focused on respondents' risk perceptions, emotional feelings and confidence in mitigating policies such as reduced extraction and damage compensation. On average, participants appeared

\footnotetext{
${ }^{6}$ The term 'gas colony' was coined for the title of a thorough journalistic account of the interactions, many via letters and E-mails, between the responsible Ministry of Economic Affairs, field operator NAM and the state's mining supervisor SodM. See Brandsma et al (2016, in Dutch).
} 
most concerned about further building damage, reductions in property value and a negative image of their region. At the time, they revealed feelings of powerlessness rather than fear or anger about seismic risks, while expressing doubts about the timely effectiveness of possible mitigation policies. In a recent follow-up (Vrieling et al. 2018), these public concerns appeared to have grown, now with powerlessness, worry, anger, disappointment and indignation reported as the strongest emotions.

From a coordinated social-psychological and publichealth study, Postmes et al. (2018) report that over 400,000 Groningers are living in areas with recognized earthquake damage. All household members included, an estimated 170,000 people have been personally affected by building damage, some 68,000 of whom are victims of multiple damages. More than $50 \%$ of the latter seem to feel no longer safe in their own home.

Personal experience of earthquakes and building damage appears to elicit feelings of insecurity, particularly in repeated and/or multiple cases. Along with complicated problems of damage settlement, such feelings eventually lead to stress-related health complaints such as poor sleep, loss of concentration, depressive states and cardiovascular troubles. Combinations of these affections occasionally lead to work absenteeism and symptoms of burn-out. Various health complaints may be exacerbated by chronic feelings of powerlessness and social inequity.

The various social and personal problems summarized above are more principally characterized in a recent verdict by the Netherlands Council of State (Raad van State 2017), acting on the request of several local authorities, interest groups and organizations who had appealed against the minister of EA's 2016 and modified 2017 approval of a 5-year plan for extracting 24 , later $21.6 \mathrm{bcm}$ per year, respectively (EZ 2016, 2017).

In their point 18 the Council notes that the nature and the scale of the consequences of Groningen gas extraction may infringe upon basic human rights to living in safety, with sufficient privacy, and in undisturbed enjoyment of personal property. The Council concluded that, for insufficient ministerial consideration of basic human rights, especially life-safety, the contested decision(s) should be annulled and the 5-year gas-extraction permit renewed-under provisional approval of the latest, $21.6 \mathrm{bcm} /$ year extraction volume (EZ 2017 ) for 2018 , to be eventually enlarged to $27 \mathrm{bcm}$ in case of a cold winter.

\section{NAM actions, SodM advice and minister's decisions}

What could possibly have been, or could still be, done to relieve the many damage-afflicted and risk-exposed Groningers from their long-term predicament? To prevent and/or reduce significant earthquake damage, personal injuries and possible fatalities above the Groningen field, eight different strategies are available:

1. Decreasing gas extraction for an extended period of time.

2. Reducing temporal and spatial fluctuations in gas extraction.

3. Preventing or countering reservoir compaction.

4. Removing households/businesses from exposure to seismic hazard.

5. Strengthening vulnerable buildings and other infrastructure.

6. Self-protection and emergency assistance of potential victims.

7. Indemnifying victims of building damage and/or injury.

8. Compensating people for having to live with seismic hazards.

Since 2014, the Dutch government has developed a multifaceted policy consisting mainly of strategies 1, 2, 5 and 7 above, whereby strategies 3 and 4 are considered impractical while 6 and 8 are generally supportive. The February-March 2018 decisions (EZ 2018a, b) to quickly reduce and eventually conclude all extraction towards 2030 reflects and ultimate choice for strategy 1 .

Given the steady increase in earthquake activity since 1991 and particularly during 2001-2013 (cf. Fig. 3b), the main parties involved: field operator NAM, mining supervisor SodM ('Staatstoezicht op de Mijnen') and the Dutch minister of Economic Affairs got engaged in a rapid sequence of research, advice, debate and decision-making, whereby the annual volume of gas extracted from the Groningen field was reduced from $54 \mathrm{bcm}$ in 2013 to $21.6 \mathrm{bcm}$ by October 1st, 2017; this amounts to a 5-year reduction of $60 \%$. Due to this and to a falling international gas price, state revenues from the Groningen field substantially decreased, from a record value of $€ 13$ billion in 2013 to about $€ 2$ billion in 2016 and 2017.

After the occurrence of another serious earthquake, with $M=3.4$ and a record peak ground acceleration $(0.12 \mathrm{~g})$, near the village of Zeerijp on January 8, 2018, SodM (2018b) reiterated its January 2013 advice to reduce gas extraction to a 'probably safe' $12 \mathrm{bcm}$ per year, whereupon the (new) minister of EA announced his firm intention to follow this advice as soon as would appear reasonably possible. Meanwhile, national gas distributor GTS (2018) simultaneously advised the minister that, also in view of various export obligations, under generally mild winters at least $14 \mathrm{bcm}$ of Groningen gas would be needed.

Then, to all parties' surprise, on March 29, 2018 the minister of EA announced the cabinet's decision to entirely stop Groningen gas extraction around 2030 (EZ 2018b), when the underground reservoir would still contain about 500 
extractable bcm of gas. This long-awaited but still unexpected 'safety first' strategy would involve a rapid reduction of annual extraction from $21.6 \mathrm{bcm}$ in 2017 to less than 12 bcm in 2023 and further decreasing thereafter; see Fig. 8.

From early 2013 on, it became clear that operator NAM long preferred to stick to their 10-year permit of extracting $42.5 \mathrm{bcm}$ per year and only slowly adapted to the government's safety-driven manoeuvers to lower the annual volume.

Given his double responsibility, for national energy supply and environmental safety, the minister of Economic Affairs also wanted to stay by NAM's running permit of $42.5 \mathrm{bcm} /$ year (on average), and he only slowly gave in to outside societal and judicial pressure to order a stepwise lowering of the annual volume. Actually, going from $54 \mathrm{bcm}$ in 2013 down to 21.6 by October 1, 2017, it took the minister seven decision steps.

In between the NAM and the minister stands mining supervisor SodM, who are both critical of NAM and critically assisting the minister. In their initial advice after the worrying 3.6 quake near Huizinge in August 2012, SodM (2013) recommended a considerable reduction in annual extraction as well as the reinforcement of thousands of vulnerable buildings; see also Muntendam-Bos and De Waal (2013).

In June 2015, SodM (2015a) advised the minister to establish a numerical standard for the individual fatality risk of a few hundred thousand inhabitants, and to reduce annual gas extraction as far as necessary to meet this standard. In December 2015, SodM (2015b) welcomed a maximum fatality probability of $10^{-5}$ per year, and they expressed their belief that 'the system' could be safely managed, especially via reduced and 'flatter' gas extraction, in both time (seasons) and space (sub-regions).

In response to a highly critical report of the Dutch Safety Board (OvV 2015) emphasizing decades-long government neglect of residents' safety, in May 2015 the Dutch minister of Economic Affairs institutionalized a 'National Coordinator Groningen' comprising a staff of about 100 civil servants for improving the massive EQ damage recording, repair and compensation, and for inspecting and planning the reinforcement of thousands of vulnerable buildings and other infrastructure (NCG 2016).

Major interventions in ministerial decision-making on the Groningen field were the November 2015 and November 2017 verdicts of the Council of State (Raad van State $2015,2017)$, highest administrative court of the Netherlands. The 2017 verdict was already mentioned in "Societal problems in 'gas colony' Groningen”. In November 2015 the Council ordered the minister of EA to restrict Groningen gas extraction to $27 \mathrm{bcm}$ per year. Two years later, the Council left the minister with a 1-year permit of 'normally' $21.6 \mathrm{bcm}$.
The rather damaging 3.4 earthquake near Zeerijp on January 8, 2018-the strongest in 5 years-caused considerable social and political turmoil, although the NAM (2018a) quickly declared that such a magnitude was not unlikely following their own probabilistic hazard and risk assessment. In response to 'Zeerijp', mining supervisor SodM (2018b) concluded (again) that under annual extraction of only 12 (rather than 21.6) bcm, external-safety standards would probably be met, and that-due to ongoing reservoir compaction-seismic activity would nevertheless continue to increase again.

Shortly thereafter, the minister of EA publicly pledged that Groningen gas extraction would soonest possible be reduced to the 'safe' level of $12 \mathrm{bcm}$ per year (EZ 2018a). However, already on 29 March 2018, the minister surprisingly announced the cabinet's intention to end all Groningen field operations by 2030 (EZ 2018b), since:

.. the government does not consider a continuing gas extraction, accompanied by a massive operation of damage compensation, restoration and reinforcement to be a sustainable societal outcome (translation ChV).

Finally, on November 14, 2018, the minister decided to permit NAM to extract about $19.4 \mathrm{bcm}$ during 2018-2019, with a lower limit of $15 \mathrm{bcm}$ given a 'warm' winter and a maximum of $27 \mathrm{bcm}$ given a cold winter including 'technical difficulties' (EZ 2018c). ${ }^{7}$

\section{Concluding remarks}

The Dutch province of Groningen is a tectonically inactive zone populated by about 600,000 people whose dwellings and other structures never needed to be 'earthquake-proof'. Since 1963, steady depletion of the $900 \mathrm{~km}^{2}$ large, $3 \mathrm{~km}$ deep and $100 \mathrm{~m}$ thick porous sandstone reservoir originally holding $2800 \mathrm{bcm}$ of natural gas has led to increasing compaction and, as apparent after 1990, an ever greater seismic responsivity to further extraction. Because continuing building damage, uncertain safety risks and residents' growing anxiety and stress were politically judged to be no longer acceptable, by April 2018 it became clear that annual gas extraction is likely to be rapidly decreased towards 2023 and more slowly thereafter until the level of practically zero bcm in 2030 .

One basic government failure underlying strong negative public feelings is the lack of appropriate seismic hazard and risk communication outside the professional world of

\footnotetext{
7 This 1-year-only instead of a usual 5-year decision was taken pending a change of the Dutch mining law specifying greater year-by-year government control over the operation of the Groningen field.
} 
geophysicists, technologists and economic analysts. To quote Stewart et al. (2017):

To convey a scientific message in a way that gains wide acceptance requires a simplified message stripped of the usual technical caveats. (..) [this] requires hazard scientists to better understand the social psychology of how people receive and process information, and in doing so learn how best to frame the intricacies, uncertainties and limitations of their intricate technical science in ways that are more easily grasped by lay audiences.

At present (January 2019), it remains to be seen how well the Dutch government will actually succeed in reducing annual gas extraction. This is planned to be done especially through a ban on the use of low-calorific 'Groningen gas' by various energy-intensive industries, through the limitation of exports to Germany, Belgium and France, and through substantial conversion of imported high- to low-calorific gas via the addition of nitrogen, the latter to be produced in a new nitrogen factory operating as of 2023.

Meanwhile, the NCG's ambitious building-reinforcement operation has been greatly reduced, leaving many Groningers in confusion about the hard-to-assess safety risks of their homes ('is our house above or below standard, and when?'). At the same time, the likely development of significant seismic activity and the necessary type and scale of timely building reinforcement are being further investigated. Thus the long story of the abundant Groningen gas field will continue for some time, under the pressure of critical research questions and challenging policy problems.

Acknowledgements This paper follows up on earlier publications (Vlek, 2017, 2018) about seismic risk standards, decision grounds for acceptable risk, and the development of earthquake hazard in Groningen. The author gratefully acknowledges the instructive evaluations by several anonymous reviewers and the editors of this journal. Over recent years, valuable comments, criticisms and suggestions were obtained from energy publicist Herman Damveld (Groningen), risk analyst Robert Geerts (Enschede, NL), reservoir technologist Jacques Hagoort (Amsterdam), social psychologist Tom Postmes and mathematical statistician Marieke Timmerman (both University of Groningen). Additional input and suggestions were gratefully received from seismologist Stephen Bourne (Shell, Amsterdam), reservoir technologist Jan van Elk (NAM, Assen) and geophysicist Annemarie Muntendam-Bos (SodM, The Hague).

Open Access This article is distributed under the terms of the Creative Commons Attribution 4.0 International License (http://creativeco mmons.org/licenses/by/4.0/), which permits unrestricted use, distribution, and reproduction in any medium, provided you give appropriate credit to the original author(s) and the source, provide a link to the Creative Commons license, and indicate if changes were made.

\section{Appendix}

Inventory of all induced, separate (i.e., declustered) earthquakes over 1991-2018 in the Groningen field

\begin{tabular}{|c|c|c|c|c|c|c|c|c|c|c|c|}
\hline Year, bcm cum $_{\text {. }}$ & $\geq 1.0$ & $\geq 1.5$ & $\geq 2.0$ & $\geq 2.5$ & $\geq 3.0$ & Year, $\mathrm{bcm}_{\text {cum }}$ & $\geq 1.0$ & $\geq 1.5$ & $\geq 2.0$ & $\geq 2.5$ & $\geq 3.0^{\mathrm{a}}$ \\
\hline 1991,1279 & 1 & 1 & 1 & 0 & 0 & 2005,1732 & 24 & 11 & 4 & 0 & 0 \\
\hline 1992,1320 & 2 & 0 & 0 & 0 & 0 & 2006,1765 & 42 & 20 & 6 & 2 & 1 \\
\hline 1993,1363 & 11 & 4 & 2 & 0 & 0 & 2007,1794 & 21 & 12 & 6 & 1 & 0 \\
\hline 1994,1398 & 19 & 7 & 3 & 2 & 0 & 2008,1835 & 31 & 11 & 4 & 2 & 1 \\
\hline 1995,1432 & 10 & 4 & 1 & 0 & 0 & 2009,1873 & 44 & 18 & 5 & 3 & 1 \\
\hline 1996,1474 & 7 & 2 & 1 & 0 & 0 & 2010,1924 & 34 & 16 & 5 & 2 & 0 \\
\hline 1997,1509 & 16 & 7 & 0 & 0 & 0 & 2011,1971 & 67 & 30 & 7 & 3 & 1 \\
\hline 1998,1540 & 11 & 6 & 3 & 1 & 0 & 2012,2019 & 53 & 20 & 3 & 1 & 1 \\
\hline 1999,1564 & 13 & 5 & 1 & 0 & 0 & 2013,2072 & 79 & 30 & 12 & 5 & 2 \\
\hline 2000,1585 & 10 & 8 & 4 & 2 & 0 & 2014,2115 & 61 & 19 & 9 & 5 & 1 \\
\hline 2001,1609 & 8 & 2 & 0 & 0 & 0 & 2015,2143 & 51 & 22 & 8 & 2 & 1 \\
\hline 2002,1636 & 7 & 4 & 1 & 0 & 0 & 2016,2170 & 38 & 14 & 4 & 0 & 0 \\
\hline 2003,1665 & 27 & 14 & 6 & 4 & 2 & 2017,2194 & 54 & 18 & 4 & 1 & 0 \\
\hline 2004,1698 & 16 & 6 & 1 & 0 & 0 & 2018,2213 & 31 & 15 & 4 & 2 & 1 \\
\hline
\end{tabular}

$N(M \geq .)=$. number of EQs with Richter-magnitude $M \geq .$. First and 7th columns present cumulative gas extraction since 1963, by the end of given year 
The Groningen field roughly has the form of an ellipsoid with the longest axis Uithuizen-Veendam and shortest axis Groningen (city)—Delfzijl; see Fig. 1 (top). All relevant earthquakes took place between latitudes $53.07 \mathrm{~N}$ (Wildervank) and 54.50 N (Waddenzee), and between longitudes 6.51 E (Garnwerd) and 7.01 E (Borgsweer). [Six events around bordering Oud/Nieuw Annerveen (lat. 53.07 ${ }^{\circ}$, long. $6.78^{\circ}$ ), with $1.5 \leq M \leq 2.2$ (in 1997, 1999, 2000, 2002 and two in 2008), have been incorporated in the analysis.]

a So far, only two earthquakes with $M \geq 3.5$ have occurred, one in 2006 (near Westeremden) and one in 2012 (Huizinge). On Jan. 8, 2018, a damaging 3.4 quake occurred near Zeerijp

\section{References}

Atkinson GM, Eaton DW, Ghofrani H, Walker D, Cheadle B, Schultz R, Shcherbakov R, Tiampo K, Gu J, Harrington RM, Liu Y, Van der Baan M, Kao H (2016) Hydraulic fracturing and seismicity in the Western Canada sedimentary basin. Seismol Res Lett 87(3):1-17

Baker JW (2008) An introduction to probabilistic seismic hazard analysis (PSHA). Stanford University (Cal.): Department of Civil and Environmental Engineering. https://web.stanford.edu/ bakerjw/ Publications/Baker_(2008)_Intro_to_PSHA_v1_3.pdf. Accessed Mar 2018

Bourne SJ, Oates S (2015) An activity rate model of induced seismicity within the Groningen Field (Parts 1 and 2). Assen (NL): NAM, February \& July. http://www.nam.nl/feiten-en-cijfers/onderzoeks rapporten. Accessed Nov 2018

Bourne SJ, Oates SJ (2017) Development of statistical geomechanical models for forecasting seismicity induced by gas production from the Groningen field. Neth J Geosci 96(5):175-182

Bourne SJ, Oates S, Van Elk J, Doornhof D (2014) A seismological model for earthquakes induced by fluid extraction from a subsurface reservoir. J Geophys Res Solid Earth 119:8991-9015

Bourne SJ, Oates SJ, Van Elk J (2018) The exponential rise of induced seismicity with increasing stress levels in the Groningen gas field and its implications for controlling seismic risk. Geophys J Int 213(3):1693-1700

Brandsma M, Ekker H, Start R (2016) De gaskolonie. Van nationale bodemschat tot Groningse tragedie. [The gas colony. From national treasure to Groningen tragedy.] Groningen: Uitgeverij Passage. P.O. Box 216, 9700 AE Groningen, the Netherlands

Cornell CA (1968) Engineering seismic risk analysis. Bull Seismol Soc Am 58:1583-1606

De Kam G (2016) Waardedaling van woningen door aardbevingen in Groningen: een doorrekening op 4 positie postcode niveau. [Housing value decrease through earthquakes in Groningen.]. Real Estate Res Q 15(3):45-53

Dempsey D, Suckale J (2017) Physics-based forecasting of induced seismicity at Groningen gas field, the Netherlands. Geophys Res Lett. https://doi.org/10.1002/2017GL073878 (on-line: July 2017)

EZ (2016) Definitief instemmingsbesluit gaswinning Groningen. [Definitive approval Groningen gas extraction 2016-2021]. Ministry of Economic Affairs, Sept, The Hague

EZ (2017) Wijziging Instemmingsbesluit Winningsplan Groningenveld. [Modification Authorization Decision Extraction Plan Groningen field.] Letter DGETM-EO/17074807 to 2nd Chamber of Parliament. Ministry of Economic Affairs (EZ), The Hague, 24 May

EZ (2018a) Niveau gaswinning Groningen. [Volume Groningen gas extraction.] Letter 33529/424 to the 2nd Chamber of Parliament.]. Ministry of Economic Affairs 1 February, The Hague
EZ (2018b) Gaswinning Groningen. [Groningen gas extraction.] Letter DGETM-EI/18057375 to the 2nd Chamber of Parliament.]. Ministry of Economic Affairs, The Hague, 29 March

EZ (2018c) Instemmingsbesluit Groningen gasveld 2018-2019. [Approval decision Groningen gas field 2018-2019.] The Hague: Ministry of Economic Affairs, ref. DGETM-EO/18219286, 14 November

Foulger GR, Wilson MP, Gluyas JG, Julian BR, Davies RJ (2018) Global review of human-induced earthquakes. Earth Sci Rev 178:438-514

Gerechtshof Arnhem/Leeuwarden (2018) Uitspraak 200.183.396/01 en 200.183.398/01 over vergoeding vermindering woningwaarde in Groningen. [Court of Appeal judgment about compensation of property value decrease through induced earthquakes in Groningen.]

Grasso J-R (1992) Mechanics of seismic instabilities induced by the recovery of hydrocarbons. Pure Appl Geophys 139(3/4):507-533

GTS (2018) Advies GTS inzake leveringszekerheid. [Advice GTS about security of delivery.] Letter to the minister of Economic Affairs. Gas Transport Services, 31 Jan, Groningen

Gutenberg B, Richter CF (1941) Seismicity of the Earth. Geol Soc Am Spec Pap 34:1-131

Hagoort J (2017) Empirical model for induced earthquakes in the Groningen gas field. https://www.deingenieur.nl/uploads/media/5a549 14ab5250/Empirical\%20Model\%20for\%20Induced\%20Earthqua kes\%20in\%20the\%20Groningen\%20Gas\%20Field.pdf. Accessed Nov 2018

Hettema M, Jaarsma B, Schroot BM, Van Yperen GCN (2017) An empirical relationship for the seismic activity rate of the Groningen gas field. Neth J Geosci 96(5):149-161

Keranen KM, Weingarten M, Abers GA, Bekins BA, Ge S (2014) Sharp increase in central Oklahoma seismicity since 2008 induced by massive wastewater injection. Science $345: 448-451$

KNMI (2018) List of all induced earthquakes recorded in the Netherlands since 1986. De Bilt (NL): Royal Dutch Meteorological Institute. http://cdn.knmi.nl/knmi/map/page/seismologie/all_induc ed.pdf. Accessed Mar 2018

Koster H, Van Ommeren J (2015) A shaky business: natural gas extraction, earthquakes and house prices. Eur Econ Rev 80:20-139

Mulargia F, Stark PB, Geller RJ (2017) Why is probabilistic seismic hazard analysis (PSHA) still used? Phys Earth Planet Inter 264:63-75

Muntendam-Bos AG, De Waal JA (2013) Reassessment of the probability of higher magnitude earthquakes in the Groningen gas field. The Hague, SodM, State Supervision of Mines, 16 January. http://www.sodm.nl

NAM (2013) Winningsplan Groningen. [Groningen field production plan 2013, with technical addendum]. NAM, Assen, NL

NAM (2016a, 2018) Facts and figures about gas extraction. NAM, Assen. http://www.namplatform.nl/feiten-en-cijfers/feiten-en-cijfe rs-gaswinning. Accessed Nov 2018

NAM (2016b) Winningsplan Groningen Gasveld 2016 [Extraction Plan Groningen Field 2016], incl. Technical Addenda \& Supplement. Assen: NAM. http://www.namplatform.nl/mediatheek/winningspl an-2016.html. Accessed Nov 2018

NAM (2016c) Report from the expert panel on maximum magnitude estimates for probabilistic seismic hazard and risk modelling in Groningen Gas Field. 25 April. NAM, Assen. http://www.nam.nl/ feiten-en-cijfers/onderzoeksrapporten. Accessed Nov 2018

NAM (2018a) Evaluatie en aanbevelingen voor beheersmaatregelen: Zeerijp aardbeving. [Evaluation and recommendations of control measures: Zeerijp earthquake.] Letter to mining supervisor SodM, 10 Jan. NAM, Assen. http://www.nam.nl/feiten-en-cijfers/onder zoeksrapporten. Accessed Nov 2018

NAM (2018b) Seismic risk assessment for production scenario "Basispad Kabinet" for the Groningen field. In: van Elk J, Mar-Or A, 
Geurtsen L, Valvatne P, Kuperus E, Dirk D June. Assen: NAM. http://www.nam.nl/feiten-en-cijfers/onderzoeksrapporten. Accessed Nov 2018

NCG (2016) Meerjarenprogramma Aardbevingsbestendig en Kansrijk Groningen 2017-2021. [Multiannual program 'Earthquake-resistant and Prospectful Groningen 2017-2021'.] Nationaal Coördinator Groningen. P.O. Box 3006, NL-9701 DA Groningen. http:// www.nationaalcoordinatorgroningen.nl. Accessed Nov 2018

Nepveu M, Van Thienen-Visser K, Sijacic D (2016) Statistics of seismic events at the Groningen field. Bull Earthq Eng 14(12):3343-3362

Nicholson C, Wesson RL (1992) Triggered earthquakes and deep well activities. Pure Appl Geophys 139(3/4):561-578

OvV (2015) Summary of Earthquake Risks in Groningen. An investigation into the role of the safety of citizens during the decision-making on gas extraction (1959-2014). The Hague: Onderzoeksraad voor Veiligheid (Dutch Safety Board)

Perlaviciute G, Steg L, Hoekstra EJ, Vrieling L (2017) Perceived risks, emotions, and policy preferences: a longitudinal survey among the local population on gas quakes in the Netherlands. Energy Res Soc Sci 29:1-11

Postmes T, Stroebe K et al (2018) Ervaren veiligheid, gezondheid en toekomstperspectief 2016-2017. [Perceived safety, health and future perspective 2016-2017.] Final report 'Groningen Perspective', joint project of University, Municipality and General Health Service of Groningen. http://www.groningsperspectief.nl. Accessed Jan 2018

Raad van State (2015) Uitspraak 201501544/1/A4 over gaswinning en aardbevingen in Groningen. [Verdict about gas extraction and earthquakes in Groningen.] The Hague: Council of State, 18 November

Raad van State (2017) Uitspraak 201608211/1/A1 over besluiten gaswinning Groningen. [Verdict about ministerial decisions on Groningen gas extraction.] The Hague: Council of State, 15 November 2017

Shapiro SA, Dinske C, Krueger OS (2017) Maximum magnitudes of earthquakes induced by fluid injections and productions: controlling parameters, estimations and case study examples. Soc Explor Geophys SEG Tech Progr Expand Abstr 2017:5356-5361

Simpson DW, Leith W (1985) The 1976 and 1984 Gazli, USSR, earthquakes—were they induced? Bull Seismol Soc Am 75:1465-1468

SodM (2018a) Gevolgen voor de veiligheidsrisico's en versterkingsopgave. (..). [Consequences for safety risks and the building-reinforcement operation.] The Hague: Staatstoezicht op de Mijnen. 27 June. http://www.sodm.nl

SodM (2018b) Advies Groningen gasveld n.a.v. aardbeving Zeerijp van 8 januari 2018. [Advice Groningen gas field after Zeerijp earthquake of Jan. 8, 2018.] 1 February. http://www.sodm.nl. Accessary Feb 2018

SodM, State Supervision of Mines (2013) Brief aan de minister van EZ. [Letter to the Minister of Economic Affairs.] The Hague: Staatstoezicht op de Mijnen, 22 January. http://www.sodm.nl. Accessed Nov 2017

SodM, State Supervision of Mines (2015a, b). Seismisch risico Groningenveld. Beoordeling rapportages \& advies. [Seismic risk Groningen field. Evaluation of reports, and advice.] The Hague: Staatstoezicht op de Mijnen (June \& December; same title). http:// www.sodm.nl. Accessed Oct 2017
Spetzler J, Dost B, Evers L (2018) Seismic hazard assessment of production scenarios in Groningen. Royal Dutch Meteorological Institute. Advisory report for Ministry of Economic Affairs. June, De Bilt (NL), pp 31

Stein S, Geller RJ, Liu M (2012) Why earthquake hazard maps often fail and what to do about it. Tectonophysics 562:1-25

Stewart IS, Ickert J, Lacassin R (2017) Communicating seismic risk: the geoethical challenges of a people-centred, participatory approach. Ann Geophys 60:1-17. https://doi.org/10.4401/ag7593

Utsu T (1999) Representation and analysis of the earthquake size distribution: a historical review and some new approaches. Pure Appl Geophys 155:509-535

Van Thienen-Visser K, Breunese JN (2015) Induced seismicity of the Groningen gas field: history and recent developments. The Leading Edge, special section: Injection-induced seismicity. June, pp 664-671

Van Wees JD, Buijze L, Van Thienen-Visser K, Nepveu M, Wassing BBT, Orlica B, Fokker PA (2014) Geomechanics response and induced seismicity during gas field depletion in the Netherlands. Geothermics 52:206-219

Van der Voort N, Vanclay F (2015) Social impacts of earthquakes caused by gas extraction in the province of Groningen, the Netherlands. Environ Impact Assess Rev 50:1-15

Van der Elst N, Page MT, Weiser DA, Goebel THW, Hosseini SM (2016) Induced earthquake magnitudes are as large as (statistically) expected. J Geophys Res Solid Earth 121(6):4575-4590

Vlek CAJ (2017) Groningen wordt steeds bevingsgevoeliger voor verdere gaswinning: statistische analyse, geofysische verklaring en onzekere risicobeheersing. [Groningen is getting more earthquake-prone by further gas extraction..]. Ruimtelijke Veiligheid en Risicobeleid 8(26/27):35-48 (with English summary)

Vlek C (2018) Induced earthquakes from long-term gas extraction in Groningen, the Netherlands: statistical analysis and prognosis for acceptable-risk regulation. Risk Anal 38(7):1455-1473

Vrieling L, Perlaviciute G, Steg L (2018) Uw mening over gaswinning uit het Groningen-gasveld. Rapportage Vragenlijstonderzoek Fase 5. [Your opinion about gas extraction from the Groningen field. Questionnaire study Phase 5.] University of Groningen, Department of Psychology, June

Walsh FR III, Zoback MD (2015) Oklahoma's recent earthquakes and saltwater disposal. Sci Adv. https://doi.org/10.1126/sciadv.15001 95

Weingarten M, Ge S, Godt JW, Bekins BA, Rubinstein JL (2015) Highrate injection is associated with the increase in U.S. mid-continent seismicity. Science 348:1336-1340

Zhao H, Ma F, Liu G, Feng X, Guo J (2018) Analytical investigation of hydraulic fracture-induced seismicity and fault activation. Environ Earth Sci 77:526

Zöller G, Holschneider M (2016) The maximum possible and the maximum expected earthquake magnitude for production-induced earthquakes at the gas field in Groningen, The Netherlands. Bull Seismol Soc Am 106(6):2917-2921

Publisher's Note Springer Nature remains neutral with regard to jurisdictional claims in published maps and institutional affiliations. 